\title{
Agro-economic responsiveness of radish associations with cowpea in the presence of different amounts of Calotropis procera, spatial arrangements and agricultural crops
}

\section{Responsividade agroeconômica de associações de rabanete com caupi na presença de diferentes quantidades de Calotropis procera, arranjos espaciais e safras de cultivo}

\author{
Renato Leandro Costa Nunes', Francisco Bezerra Neto², Jailma Suerda Silva de Lima², \\ Aurélio Paes Barros Júnior ${ }^{3 *}$, Aridênia Peixoto Chaves², Josimar Nogueora da Silva²
}

\author{
'Universidade Federal Rural do Semi-Arido/UFERSA, Departamento de Ciências Agronômicas e Florestal, Mossoró, RN, Brasil \\ ${ }^{2}$ Universidade Federal Rural do Semi-Arido/UFERSA, Mossoró, RN, Brasil \\ 3Universidade Federal Rural do Semi-Arido/UFERSA, Programa de Pós-Graduação em Fitotecnia, Mossoró, RN, Brasil \\ *Corresponding author: aurelio.barros@ufersa.edu.br \\ Received in April 26, 2018 and approved in August 7, 2018
}

\begin{abstract}
The integration of research emphasizing sustainable development, employment, income generation and food security has been highlighted in the media. The objective of this research was to evaluate the agro-economic responsiveness of radish associations with cowpea in the presence of different amounts of roostertree, spatial arrangements and agricultural crops. The experimental design was a randomized block design with four replications, with treatments arranged in a $4 \times 3$ factorial scheme, where the first factor consisted of four amounts of $C$. procera incorporated in the soil $\left(20,35,50\right.$ and $65 \mathrm{t} \mathrm{ha}^{-1}$ on a dry basis) and the second factor of three spatial arrangements (2:2, 3:3, and $4: 4$ ) in two cropping seasons. Radish samples were evaluated for plant height, dry mass of shoots, total and commercial productivity of roots, productivity of scrap roots, and dry mass of roots, while in cowpea, vegetation was assessed for length of green pods, number of pods per square meter, productivity and dry mass of green pods, number of green grains per pod, weight of 100 green grains, and yield and dry mass of green grains. The economic indicators of monetary advantage and modified monetary advantage were used in the evaluation of efficiency. A greater agro-economic responsiveness of the intercropping of radish and cowpea crops was obtained with the incorporation of $56.44 \mathrm{t} \mathrm{ha}^{-1}$ of $\mathrm{C}$. procera. The spatial arrangements of 3:3 and 4:4 had better agronomic and economic responsiveness. The association between radish and cowpea is feasible when the crops are fertilized with $C$. procera.
\end{abstract}

Index terms: Raphanus sativus; Vigna unguiculata; intercropping.

\begin{abstract}
RESUMO
A integração de pesquisas enfatizando o desenvolvimento sustentável, o emprego, a geração de renda e a segurança alimentar vêm sendo destaque nos meios de divulgação. Assim, o objetivo desta pesquisa foi avaliar a responsividade agroeconômica de associações de rabanete com caupi em diferentes quantidades de C. procera, arranjos espaciais e safras de cultivo. O delineamento experimental foi o de blocos casualizados com quatro repetições, em esquema fatorial $4 \times 3$, onde o primeiro fator consistiu de quatro quantidades de C. procera incorporadas ao solo (20; 35; 50 e $65 \mathrm{t} \mathrm{ha}^{-1}$ em base seca) e o segundo de três arranjos espaciais (2:2; 3:3 e 4:4) em duas safras de cultivo. Amostras de rabanete foram avaliadas quanto à altura de plantas, massa seca da parte aérea, produtividade total e comercial de raízes, produtividade de raízes refugo e massa seca de raízes, enquanto que no caupi, as amostras foram avaliadas quanto ao comprimento de vagens verdes, número de vagens por $\mathrm{m}^{2}$, produtividade e massa seca de vagens verdes, número de grãos verdes por vagem, peso de 100 grãos verdes, produtividade e massa seca de grãos verdes. Os indicadores econômicos vantagem monetária e monetária corrigida foram utilizados na avaliação da eficiência do consórcio. Uma maior responsividade agroeconômica do consórcio de rabanete e caupi foi obtida com a incorporação de 56,44 t ha-1 de C. procera. Os arranjos espaciais 3:3 e 4:4 tiveram melhor responsividade em termos agronômico e econômico. A associação entre o rabanete e o caupi é viável quando as culturas são adubadas com C. procera.
\end{abstract}

Termos para indexação: Raphanus sativus; Vigna unguiculata; consorciação de culturas.

\section{INTRODUCTION}

Currently, in Brazil, the use of different methods for agricultural production within family agriculture has been gaining strength, mainly due to the modernization of research emphasizing sustainable development, employment, income generation and food security.

Among these methods of production, the use of crop association has several advantages, including the most intensive use of agricultural areas, a reduction in the risk 
of cultural failure, increased vegetative protection of the soil against erosion, better control of weeds due to greater soil vegetative cover velocity and the most efficient use of labor (Vieira et al., 2006).

The use of short-cycle plants, such as vegetable crops, is a viable alternative for income generation with a rapid economic return on rural property (Oliveira et al., 2015). Among such crops, associations between the radish (Raphanus sativus L.), belonging to the Brassicaceae family with a short life cycle and low soil fertility requirements (Silva et al., 2015), and the cowpea (Vigna unguiculata (L.) Walp), belonging to the Fabaceae family with the characteristic of being able to establish symbiotic relationships with nitrogenfixing bacteria in the soil, favor improvements in soil fertility and the use of environmental resources.

In crop associations, one of the viable alternatives for supplying nutrient demand to vegetable crops is green manuring, characterized by the incorporation of non-decomposed plant matter grown on- or off-site into the soil to preserve and restore organic matter and soil nutrient contents (Calegari et al., 1993). In the Caatinga biome, for example, there are several species with potential for use in the green manuring of vegetables, including hairy woodrose (Merremia aegyptia L.), oneleaf senna (Senna obtusifolia L. Irwin \& Barneby) and roostertree (Calotropis procera (Ait.) R. Br.) (Batista et al., 2013).

$C$. procera has aroused the interest of researchers in its native region due to its adaptation, biomass production, regrowth and availability of nutrients present, which in decomposition may be available for crops present in an association relationship. Spontaneous species can be used as a strategy for green manuring in several types of intercropping systems. Research has shown the agronomic viability of the use of $C$. procera as a green manure in intercropping, since it promotes an increase in yields of the commercial roots of radish and cowpea (Pereira et al., 2016).

In addition to the previous methods, the increase in productivity of radish-cowpea association depends on, among other factors, management related to the distribution of plants in the field of the crops involved. In other words, the search for a spatial arrangement between component cultures that provides a more uniform distribution of plants by area allows a better use of light, water and nutrients (Argenta et al., 2001), contributing to different combinations of species that can increase crop yields relative to monocultures (Favacho et al., 2017). It is worth noting that spatial arrangements can also affect the production characteristics and productivities of many crops (Bezerra et al., 2014). However, studies carried out in the northeastern semi-arid region of Brazil report that in the association between carrot and cowpea, tuberose presented the best use of environmental resources in the 2:2 arrangement for commercial roots (Ribeiro et al., 2018).

Therefore, there are still several challenges related to the success of intercropped cultivations associated with green manuring, and the choice of an appropriate spatial arrangement between radish and cowpea crops that improves complementarity or even minimizes intraor interspecific competition optimizes the productive potential of the cultures present in the system.

In view of the above, the objective of this study was to evaluate the agro-economic responsiveness of the association between radish and cowpea in the presence of different amounts of $C$. procera, spatial arrangements and agricultural crops.

\section{MATERIAL AND METHODS}

Two experiments were carried out between August and November of 2015 and 2017 at the Rafael Fernandes Experimental Farm belonging to the Universidade Federal Rural do Semi-Árido (UFERSA), located in the district of Alagoinha, (5 $5^{\circ} 11^{\prime} 31^{\prime \prime} \mathrm{S}$ and $37^{\circ} 20^{\circ} 40^{\prime \prime} \mathrm{W}, 18 \mathrm{~m}$ altitude). The climate in this region, by the classification of Köppen, is BShw, i.e., dry, very hot and with a rainy season in the summer, reaching average maximum temperatures between 32.1 and $34.5^{\circ} \mathrm{C}$ and minimum averages between 21.3 and $23.7^{\circ} \mathrm{C}$, with June and July being the coldest months and average annual precipitation being approximately $685.3 \mathrm{~mm}$.

Figure 1 shows the maximum, average and minimum temperatures and solar radiation of the summers of 2015 and 2017, in which we tested the association between radish and cowpea in the summers of 2015 and 2017.

The experimental design was of randomized complete blocks with four replications, with treatments arranged in a $4 \times 3$ factorial scheme, where the first factor consisted of four amounts of $C$. procera incorporated into the soil $\left(20,35,50\right.$ and $65 \mathrm{t} \mathrm{ha}^{-1}$ on a dry basis) and the second factor of three spatial arrangements $(2: 2,3: 3$ and $4: 4)$ in two crop seasons.

The cultivars sown included, for radish, cv. Giant Crimson, and for cowpea, cv. BRS Itaim, which were recommended for cultivation in the semi-arid region of Northeast Brazil. Intercropping cultivation was established in alternating strips of the component cultures in the proportion of $50 \%$ of the area for radish and $50 \%$ of the area for cowpea, where each plot consisted of a particular number of radish rows alternated with a particular number of cowpea rows, according to the spatial arrangement to 
be studied and flanked by two rows of radish borders on one side and two rows of cowpea on the other side, thus constituting the lateral borders. The total and harvest areas of each plot were established according to the spatial arrangements studied (2:2, 3:3 and 4:4). For this study, the total areas were of $2.4,3.0$ and $3.6 \mathrm{~m}^{2}$, respectively. The harvest areas of both cultures were 1.0, 1.5 and $2.0 \mathrm{~m}^{2}$ The number of evaluated plants for each culture was also established according to the spatial arrangements studied (2:2, 3:3 and 4:4), with 50, 75 and 100 radish plants for the $0.25 \mathrm{~m} \times 0.04 \mathrm{~m}$ spacing and with 20,30 and 40 cowpea plants for the $0.25 \mathrm{~m} \mathrm{x} 0.10 \mathrm{~m}$ spacing.

In each block, at optimum population densities recommended by the literature, plots of single-crop radish and cowpea were planted to obtain the agro-economic efficiency indicators of intercropping. The total areas of the single plots of radish and cowpea were 1.44 and 3.60 $\mathrm{m}^{2}$, with harvest areas of 0.80 and $2.0 \mathrm{~m}^{2}$, respectively. In these plots, radish spacing was $0.20 \mathrm{~m}$ between rows and $0.10 \mathrm{~m}$ between plants, with a population density of 500,000 plants per hectare (Batista et al., 2013), while that of cowpea was $0.50 \mathrm{~m}$ between rows and $0.10 \mathrm{~m}$ between plants, with a population density of 200,000 plants per hectare (Freire Filho, 2011).

The soil of the experimental area was classified as typical dystrophic red Argisolic, according to Rêgo et al. (2016), containing the sand, silt and clay contents shown in Table 1.

Soil preparation of the experimental areas consisted of plowing and harrowing, followed by lifting of the beds. Before the field work, a 45-day solarization of plantation beds was carried out, aiming to reduce the soil phytopathogen population, which could have affected the productivity of the evaluated crops.

Before the installation of the field experiments, soil samples from the experimental area were collected and sent for analysis to the Soil Fertility Laboratory of the UFERSA, with the results shown in Table 2.
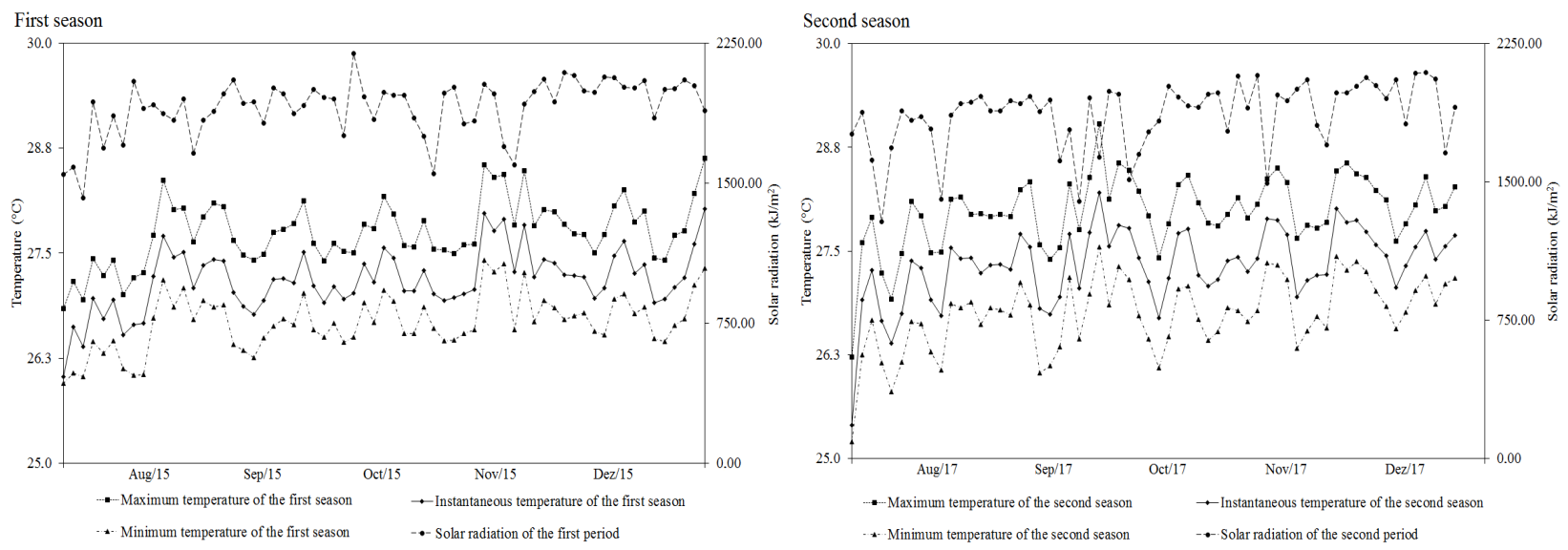

Figure 1: Climatic data provided by INMET (National Institute of Meteorology), related to the planting seasons in the summers of 2015 and 2017 in Mossoró-RN.

Table 1: Physical attributes of the soil profile of the experimental area.

\begin{tabular}{|c|c|c|c|c|}
\hline \multirow{3}{*}{$\begin{array}{c}\text { Depth * } \\
\text { (cm) }\end{array}$} & Coarse sand & Fine sand & Silt & Clay \\
\hline & \multicolumn{4}{|c|}{-----------.g kg-1----------- } \\
\hline & \multicolumn{4}{|c|}{ Soil profile of the Typical dystrophic red Ultisol } \\
\hline$A(0-22)$ & 729 & 192 & 20 & 59 \\
\hline$A B(22-47)$ & 580 & 262 & 27 & 131 \\
\hline BA (47-107) & 502 & 238 & 42 & 219 \\
\hline Bt1(107-183) & 487 & 239 & 48 & 226 \\
\hline $\mathrm{Bt} 2\left(183-233^{+}\right)$ & 419 & 165 & 48 & 369 \\
\hline
\end{tabular}

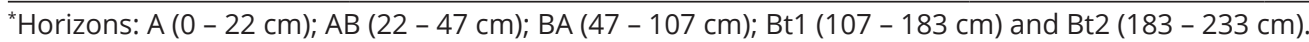


Table 2: Chemical analysis of the soil before incorporation of $C$. procera in the first and second cropping season.

\begin{tabular}{|c|c|c|c|c|c|c|c|c|c|c|c|c|c|}
\hline \multicolumn{14}{|c|}{ Prior to incorporation of C. procera } \\
\hline \multirow{2}{*}{$\begin{array}{c}\text { Cropping } \\
\text { season }\end{array}$} & \multirow{2}{*}{$\begin{array}{c}\mathrm{N} \\
\mathrm{g} \mathrm{kg}^{-1}\end{array}$} & \multirow{2}{*}{$\begin{array}{c}\mathrm{pH} \\
\text { (water) }\end{array}$} & \multirow{2}{*}{$\begin{array}{c}\text { EC } \\
\text { ds } \mathrm{m}^{-1}\end{array}$} & \multirow{2}{*}{$\begin{array}{l}\text { O.M. } \\
\mathrm{g} \mathrm{kg}^{-1}\end{array}$} & $\mathrm{P}$ & $\mathrm{K}^{+}$ & $\mathrm{Na}^{+}$ & $\mathrm{Ca}^{2+}$ & $\mathrm{Mg}^{2+}$ & $\mathrm{Cu}$ & $\mathrm{Fe}$ & $\mathrm{Mn}$ & $\mathrm{Zn}$ \\
\hline & & & & & \multicolumn{3}{|c|}{$\mathrm{mg} \mathrm{dm} \mathrm{m}^{-3}$} & \multicolumn{2}{|c|}{$\mathrm{cmol}_{\mathrm{c}} \mathrm{dm}^{-3}$} & \multicolumn{4}{|c|}{$\mathrm{mg} \mathrm{dm} \mathrm{m}^{-3}$} \\
\hline 1 & 0.51 & 7.46 & 1.77 & 3.64 & 63.3 & 60.0 & 17.0 & 2.09 & 0.58 & 0.19 & 2.03 & 10.43 & 6.21 \\
\hline 2 & 0.42 & 6.60 & 0.10 & 3.65 & 34.2 & 69.2 & 19.0 & 3.10 & 0.80 & 0.29 & 2.86 & 11.40 & 7.35 \\
\hline
\end{tabular}

The carbon percentage was determined by dichromatometry, and total nitrogen was determined by the Kjeldahl method. The $\mathrm{pH}$ analysis was performed using a potentiometer in a soil suspension of 1:2.5 in water. For $\mathrm{P}$ and $\mathrm{K}$ content, the Mehlich solution $\left(\mathrm{HCl} 0.05 \mathrm{~mol} \mathrm{~L}^{-1}\right.$ $\mathrm{H} 2 \mathrm{SO} 4+0.025 \mathrm{~mol} \mathrm{~L}^{-1}$ ) extractor was used, and $\mathrm{P}$ and $\mathrm{K}$ were determined by calorimetry and flame photometry, respectively. Sodium was determined by dilute hydrochloric acid solution and was subsequently determined using a flame spectrophotometric apparatus. The contents of calcium and magnesium were obtained by extraction with $1 \mathrm{~mol} \mathrm{~L}^{-1} \mathrm{KCl}$ and quantified by atomic absorption spectrophotometry and by titration, respectively, with $0.01 \mathrm{~mol} \mathrm{~L}^{-1} \mathrm{NaOH}$. The $\mathrm{Cu}, \mathrm{Fe}, \mathrm{Mn}$ and $\mathrm{Zn}$ contents were determined by the methodologies recommended by Embrapa (2009).

The $C$. procera was collected in localities near Mossoró and then crushed in a conventional forage machine, obtaining fragments between two and three centimeters that were placed to dry until reaching hay condition $(10 \%$ moisture). From samples of this material, the nutrient contents in the dry matter were determined according to Table 3.

The chemical analyses for the determination of the nutrient contents present in each fraction of $C$. procera were conducted using extracts obtained via sulfur digestion. Nitrogen was quantified by the Kjeldahl semimicro method, phosphorus by the spectrometry method with vanadium yellow, and potassium and sodium using the method of emission flame spectrometry. The $\mathrm{C} / \mathrm{N}$ ratio was obtained by dividing the total carbon contents by total $\mathrm{N}$ contents in each sample of green manure. Total carbon content was determined by the method of firing in a muffle at a temperature of $550{ }^{\circ} \mathrm{C}$ (Silva; Queiros, 2002). The contents of calcium, magnesium, iron, zinc, copper, and manganese were quantified by the spectrometry method of atomic absorption, sulfur by the turbidimetry method, and boron by the azimetric method (Embrapa, 2009).

The $C$. procera plant is adapted to the soil and climatic conditions of the Caatinga biome, generally presenting high biomass production and a $\mathrm{C} / \mathrm{N}$ ratio less than 30/1, which favors the mineralization process, in detriment to immobilization (Linhares et al., 2011).
The chemical composition of the entire plant is $73.8 \%$ moisture, $40.3 \%$ carbon, 6.19 hydrogen, 2.06 nitrogen and $0.92 \%$ ash, on average (Costa et al., 2009).

The manure was incorporated into the $0-20 \mathrm{~cm}$ soil layer at 20 days before sowing of the component cultures. The incorporation of this green manure for monocrops of radish and cowpea were carried out at doses of 18 and $59 t$ $\mathrm{ha}^{-1}$, respectively, according to optimized amounts obtained from previous research (Batista et al., 2013; Vieira et al., 2018). After incorporation of $C$. procera into the soil, daily irrigations were carried out in two shifts, with the purpose of favoring soil microbial activity in the process of mineralization of organic matter. Component crop planting was carried out on August 28, 2015, and August 18, 2017, via direct sowing at two centimeters deep. After emergence of the crops, thinning occurred at 7 and 10 days for radish and cowpea, respectively, leaving one plant per sowing hole. Manual weedings were performed where necessary.

During the experiments, daily irrigations were carried out by a micro-sprinkler system. The amount of water supplied was determined via the values of the cowpea cultivation coefficient (initial $\mathrm{K}_{\mathrm{ch}}=0.5$, medium $\mathrm{K}_{\mathrm{ch}}=1.05$ and final $\mathrm{K}_{\mathrm{ch}}=0.90$ ) (Allen et al., 1998), with a daily application of 14 to $16 \mathrm{~mm}$ (Lima et al., 2010). The radish harvest occurred at 30 days after sowing. Three harvestings of cowpea occurred at 51 to 65 days after sowing in the first season and at 50 to 62 days after sowing in the second season.

Characteristics evaluated in the radish were: plant height, dry mass of shoots, total and commercial productivity of roots, productivity of scrap roots and dry mass of roots. Green pod length, number of pods per $\mathrm{m}^{2}$, productivity and dry mass of green pods, number of green grains per pod, weight of 100 green grains, yield and dry mass of green grains were determined for cowpea.

Gross income, total production costs per hectare of each plot and net income were quantified (Table 4). Based on these values, the agro-economic efficiency indicators for evaluation of the association were determined through monetary advantage and modified monetary advantage values (Oliveira et al., 2015). 
Table 3: Macro and micronutrient contents in C. procera biomass and C/N ratio in the first and second cropping seasons.

\begin{tabular}{|c|c|c|c|c|c|c|c|c|c|c|c|}
\hline \multirow{2}{*}{$\begin{array}{l}\text { Cropping } \\
\text { season }\end{array}$} & \multicolumn{5}{|c|}{$\begin{array}{c}\text { Macronutrient contents in the green } \\
\text { manure }\left(\mathrm{g} \mathrm{kg}^{-1}\right)\end{array}$} & \multicolumn{5}{|c|}{$\begin{array}{c}\text { Micronutrient contents and sodium in the } \\
\text { green manure }\left(\mathrm{mg} \mathrm{kg}^{-1}\right)\end{array}$} & \multirow[t]{2}{*}{$\mathrm{C} / \mathrm{N}$ ratio } \\
\hline & $\mathrm{N}$ & $\mathrm{P}$ & K & $\mathrm{Ca}$ & $\mathrm{Mg}$ & $\mathrm{Fe}$ & $\mathrm{Mn}$ & $\mathrm{Zn}$ & $\mathrm{Cu}$ & $\mathrm{Na}$ & \\
\hline 1 & 18.40 & 3.10 & 14.50 & 16.30 & 13.50 & 100.5 & 21.75 & 37.88 & 3.85 & 608.5 & $25: 1$ \\
\hline 2 & 15.30 & 0.66 & 25.60 & 8.60 & 4.32 & 94.3 & 16.24 & 29.77 & 3.04 & 207.3 & $25: 1$ \\
\hline
\end{tabular}

The monetary advantage value was expressed by the Equation 1 (Dhima et al., 2007):

$M A=G I \times \frac{L E R-1}{L E R}$

where MA is monetary advantage $\left(\mathrm{R} \$ \mathrm{ha}^{-1}\right)$, GI is gross income per hectare $\left(\mathrm{R} \$ \mathrm{ha}^{-1}\right)$ and LER is land equivalent ratio. The modified monetary advantage value was expressed by the Equation 2:

$$
M M A=N I \times \frac{L E R-1}{L E R}
$$

where MMA is modified monetary advantage $\left(\mathrm{R} \$ \mathrm{ha}^{-1}\right)$ and NI is net income per hectare $\left(\mathrm{R} \$ \mathrm{ha}^{-1}\right)$.

Univariate analysis of variance for the randomized block design in a factorial scheme was used to evaluate the variables. The procedure for adjusting regression curves using Table curve software was used to estimate the behavior of each variable as a function of the amounts of $C$. procera applied (Jandel Scientific, 1991). A joint analysis for the two growing seasons was carried out. Tukey's test was used to compare the means between spatial arrangements and growing seasons through the SISVAR software (Ferreira, 1998).

\section{RESULTS AND DISCUSSION}

The results of the analysis of variance of the radish characteristics evaluated in this study are presented in Table 5. Significant interactions were observed between cultivation times and amounts of $C$. procera incorporated into the soil for the variables total and commercial productivity of roots, and between quantities of $C$. procera and spatial arrangements for the variable dry mass of roots (Table 5).

Partitioning the amounts $C$. procera within each growing season, we observed upward responses of the total and commercial productivities of roots as a function of the amounts of $C$. procera, with maximum values of 5.70 and $5.08 \mathrm{t} \mathrm{ha}^{-1}$, respectively, following the applied amounts of 62.70 and $65.00 \mathrm{tha}^{-1}$, respectively, in the first growing season, and with maximum values of 8.56 and $7.60 \mathrm{tha}^{-1}$, respectively, following the applied amounts of 49.56 and $46.69 \mathrm{tha}^{-1}$, respectively, in the second season, then decreasing up to the last added amount (Figure 2C).

These decreases in radish productivities after maximum points can be explained by the Maximum Law, where the excess of a nutrient in the soil can cause a toxic effect and/or cause a decrease of the efficacy of others, thus reducing crop production (Almeida et al., 2015). Pereira et al. (2016) studied the association of radish with cowpea in the same region as our research and observed a decrease in the total and commercial productivities of radish until the addition of the last dose of $C$. procera was incorporated into soil after reaching maximum green manure values of 47.97 and $49.86 \mathrm{tha}^{-1}$, respectively. Almeida et al. (2015) obtained the same decreasing pattern of lettuce productivity and yield of arugula green mass in lettucearugula intercroppings fertilized with $C$. procera.

On the other hand, this increase is due, in part, to the greater availability of nutrients released by green manure, as well as the synchrony in which these elements are released and absorbed by the plant during the cycle of the component crops (Bezerra Neto et al., 2014). Batista et al. (2013), studying the manuring of radish in single-cropping with $C$. procera, observed total and commercial productivity values of roots of 8.27 and $7.01 \mathrm{tha}^{-1}$, superior to the of first season and inferior to the of the second season values registered in this work. From this, regardless of the years of cultivation, we can infer that this tuberous vegetable responded well to green manuring using $C$. procera.

Partitioning the amounts of $C$. procera applied within each spatial planting arrangement, it was also observed an increase in dry mass of roots as a function of the amounts of C. procera incorporated in the soil, with maximum values of $0.37,0.41$ and $0.46 \mathrm{t} \mathrm{ha}^{-1}$ following the applied amounts of $48.20,50.76$ and $60.42 \mathrm{t} \mathrm{ha}^{-1}$ for the $2: 2,3: 3$ and $4: 4$ arrangements, respectively, decreasing to the last amount added (Figure 2D). These decreases after the optimized values were due to proper application of nutrients to the soil that promoted an increase in plant yield up to a maximum point, subsequent to which the response became negative, thus producing a decrease in yield, behavior explained by the maximum law reported by Almeida et al. (2015). 
$\frac{5}{5}$

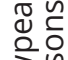

药密

둗을

노일

은

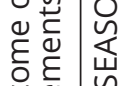

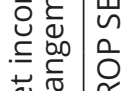

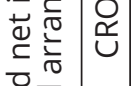

등 $\frac{\pi}{\pi}$

은

כ)

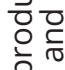

演

苟兵

음

范

엉

है을

흘

n.

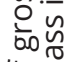

पे है

뜨응

$\frac{\pi}{2} \frac{0}{2}$

$\ddot{\forall}$

ช ذิ

更证

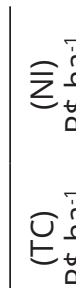

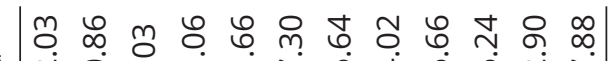

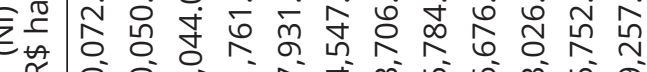
읃ㄷํ்

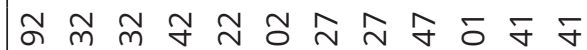
ひ身

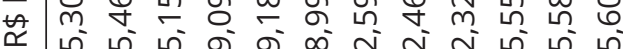
-

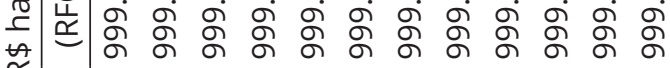

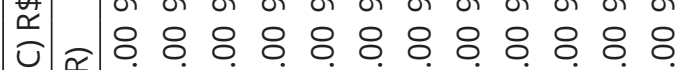

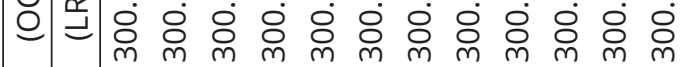
殸

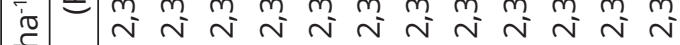
* ○ी 눈 -

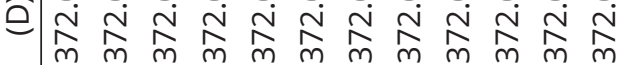

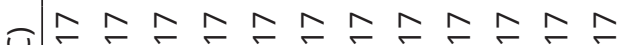
¿

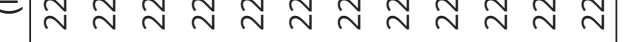

ய

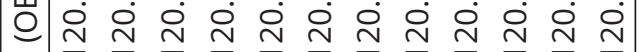

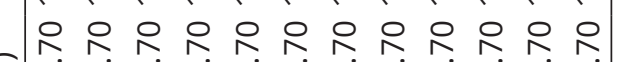

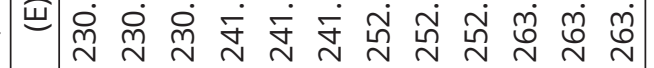

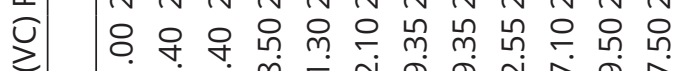
己

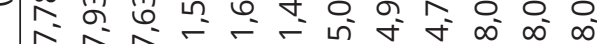
이 =

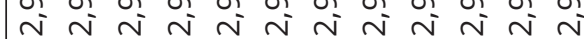

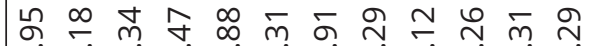

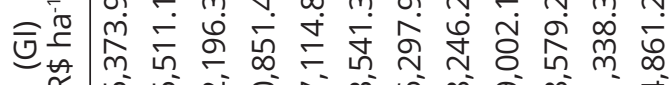

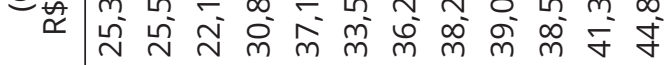

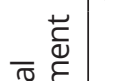

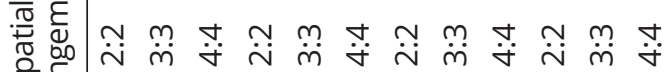

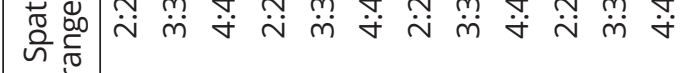

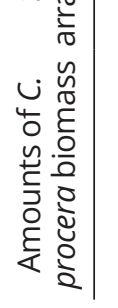

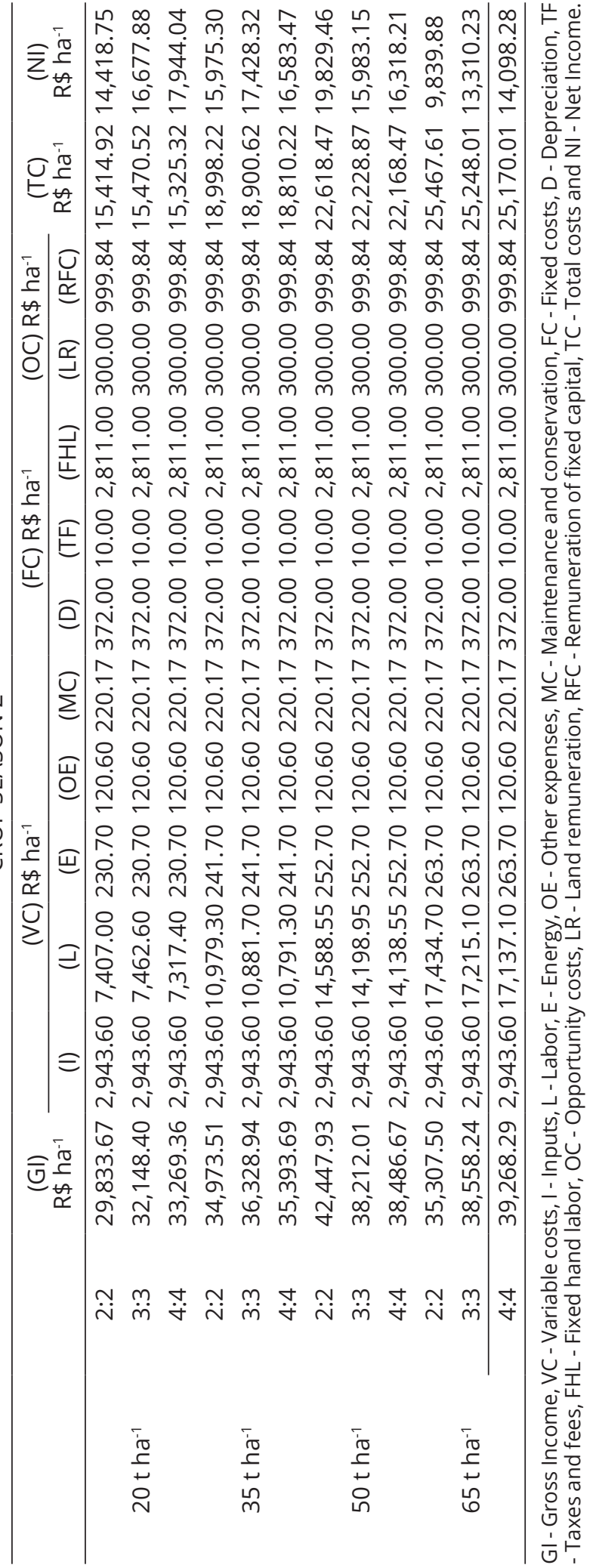


Table 5: Fvalues for plant height (PH), dry mass of shoots (DMS), total productivity (PTR) and commercial productivity of roots (PCR), productivity of scrap roots (PSR) and dry mass of roots (DMR) of radish intercropped with cowpea at two different growing seasons, in the amounts of $C$. procera incorporated into the soil and in spatial arrangements.

\begin{tabular}{|c|c|c|c|c|c|c|c|}
\hline Sources of variation & DF & $\mathrm{PH}$ & DMS & PTR & PCR & PSR & DMR \\
\hline Blocks (Seasons) & 6 & $7.28^{\star *}$ & $4.50^{* *}$ & $3.06^{* *}$ & $3.78^{* *}$ & $2.09^{\mathrm{ns}}$ & $0.67^{\mathrm{ns}}$ \\
\hline Seasons (S) & 1 & $22.05^{\star *}$ & $142.20^{\star *}$ & $321.48^{* *}$ & $204.64^{* *}$ & $18.89^{* *}$ & $157.63^{\star \star}$ \\
\hline Amounts (Q) & 3 & $18.23^{* *}$ & $13.19^{* *}$ & $17.06^{* *}$ & $14.45^{* *}$ & $0.35^{\text {ns }}$ & $10.69^{* *}$ \\
\hline Spatial arrangements (A) & 2 & $0.19^{\text {ns }}$ & $14.60^{* *}$ & $15.60^{* *}$ & $8.27^{\star \star}$ & $6.07^{* *}$ & $11.08^{* *}$ \\
\hline$S \times Q$ & 3 & $1.13^{\mathrm{ns}}$ & $0.43^{\text {ns }}$ & $3.25^{*}$ & $3.71^{*}$ & $2.47^{\text {ns }}$ & $2.47^{\mathrm{ns}}$ \\
\hline$S \times A$ & 2 & $2.18^{\text {ns }}$ & $1.16^{\mathrm{ns}}$ & $0.01^{\mathrm{ns}}$ & $0.15^{\mathrm{ns}}$ & $0.75^{\text {ns }}$ & $2.23^{\text {ns }}$ \\
\hline $\mathrm{Q} \times \mathrm{A}$ & 6 & $1.23^{\text {ns }}$ & $1.95^{\mathrm{ns}}$ & $0.79^{\text {ns }}$ & $0.46^{\mathrm{ns}}$ & $0.48^{\text {ns }}$ & $2.69^{*}$ \\
\hline$S \times Q \times A$ & 6 & $1.27^{\mathrm{ns}}$ & $1.94^{\text {ns }}$ & $1.47^{\mathrm{ns}}$ & $1.03^{\text {ns }}$ & $0.45^{\text {ns }}$ & $1.93^{\text {ns }}$ \\
\hline CV (\%) & - & 11.11 & 19.82 & 13.80 & 18.04 & 42.21 & 17.46 \\
\hline
\end{tabular}

** $=\mathrm{P}<0.01 ; *=\mathrm{P}<0.05 ; \mathrm{ns}=\mathrm{P} \geq 0.05$.

A

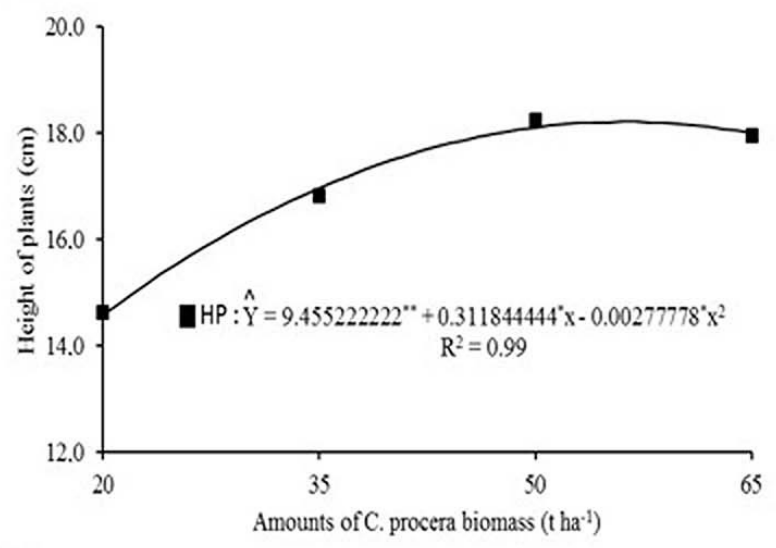

C

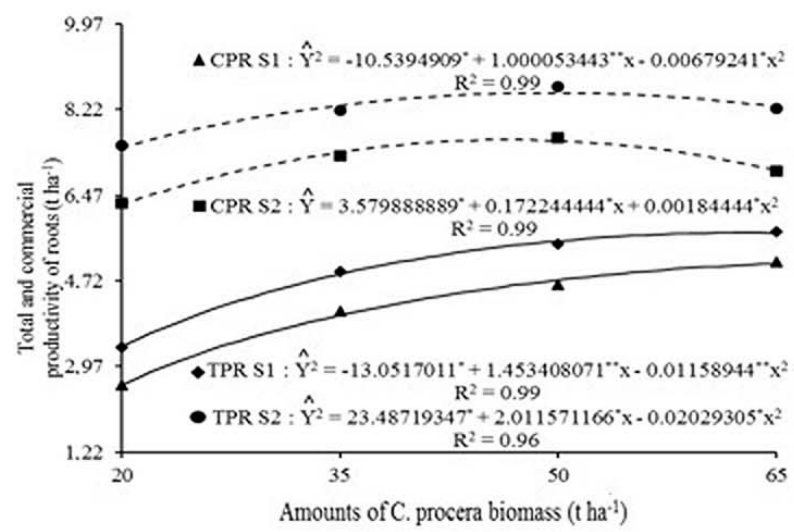

B

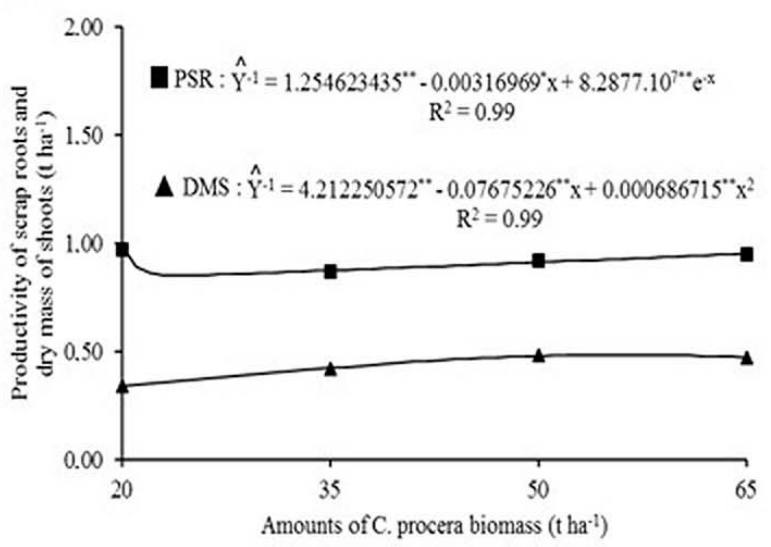

D

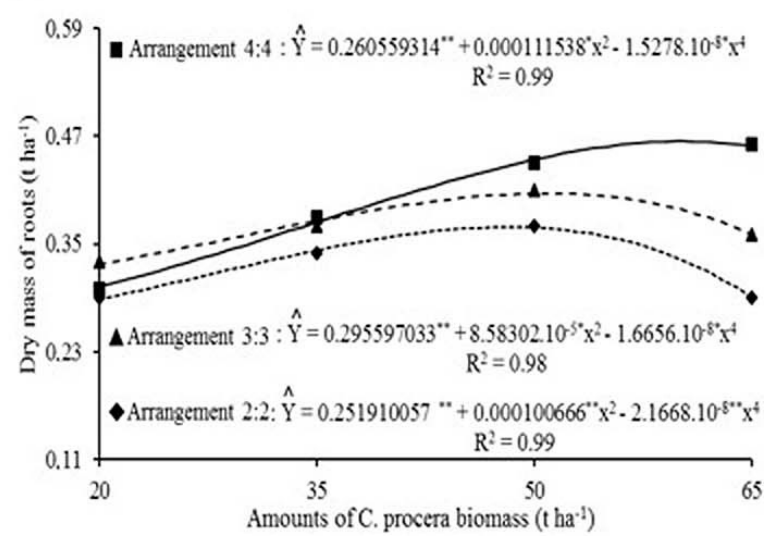

Figure 2: Height of plants (A), productivity of scrap roots and dry mass of shoots (B), total and commercial productivities of roots (C) and dry mass of roots (D) of radish intercropped with cowpea in two different growing seasons and with different amounts of $C$. procera incorporated into the soil. 
The variables of plant height and shoot dry mass increased as a function of $C$. procera amounts, obtaining maximum values of $18.21 \mathrm{~cm}$ and $0.48 \mathrm{t} \mathrm{ha}^{-1}$ following the applied amounts of 56.13 and $55.88 \mathrm{t} \mathrm{ha}^{-1}$, respectively, then decreasing until the last amount was added to the soil (Figures 2A and 2B). The productivity of scrap roots showed a stable behavior $\left(0.90 \mathrm{t} \mathrm{ha}^{-1}\right)$ up to the last amount incorporated into soil, $65 \mathrm{t} \mathrm{ha}^{-1}$ (Figure 2B).

Table 6 shows the partitioning of the cropping seasons within each amount of $C$. procera incorporated into the soil for the total and commercial productivity of root variables and for the spatial arrangements within the $C$. procera treatments for dry mass of radish roots. Significant differences were recorded between growing season productivities, with the averages of the second season standing out from those of the first season. These differences can be related to the competitive and productive behaviors of the cowpea between growing seasons, since its performance was inferior in the second season, positively favoring radish performance in this same cropping. For dry mass of roots, a significant difference was observed between spatial arrangements for the treatment incorporating $65.00 \mathrm{t} \mathrm{ha}^{-1}$ of $C$. procera biomass, with the 4:4 arrangement surpassing the others. This performance can be attributed to the influence of greater intraspecific competition for environmental resources. Thus, in spite of a greater intraspecific competition between the radish plants in the harvest area of the 4:4 arrangement compared to the other spatial arrangements, they were able to present an amount of dry mass of roots superior to radishes from the other arrangement treatments at the end of the cycle.

Significant differences in plant height, dry mass of shoots, productivity of scrap roots and dry mass of roots as a result of crop season were observed, with the second season standing out from the first (Table 7). This difference may be related to the morphological growth pattern of cowpea, possibly causing shading of the lower parts of the radish plants, resulting in a positive change in root yield of radish. Significant differences between the spatial arrangements of intercropped radish with cowpea were observed between dry mass of shoots and total and commercial productivities of roots, with the 3:3 and 4:4 arrangements standing out from the 2:2 arrangement.

Table 6: Productivities of total (PTR) and commercial (PCR) roots of radish in the crop seasons within different amounts of $C$. procera incorporated into the soil, and dry mass of radish roots (DMR) in different spatial arrangements within each $C$. procera treatment.

\begin{tabular}{cccccccc}
\hline Incorporated amount & \multicolumn{2}{c}{$\begin{array}{c}\text { PTR } \\
\left(\mathrm{t} \mathrm{ha}^{-1}\right)\end{array}$} & \multicolumn{2}{c}{$\begin{array}{c}\text { PCR } \\
\left(\mathrm{t} \mathrm{ha}{ }^{-1}\right)\end{array}$} & \multicolumn{3}{c}{$\begin{array}{c}\text { DMR } \\
\left(\mathrm{t} \mathrm{ha}^{-1}\right)\end{array}$} \\
\hline & $1^{\text {st }}$ season & $2^{\text {nd }}$ season & $1^{\text {st }}$ season & $2^{\text {nd }}$ season & $2: 2$ & $3: 3$ & $4: 4$ \\
\hline 20 & $3.36 \mathrm{~b}$ & $7.49 \mathrm{a}$ & $2.58 \mathrm{~b}$ & $6.31 \mathrm{a}$ & $0.29 \mathrm{a}$ & $0.33 \mathrm{a}$ & $0.30 \mathrm{a}$ \\
35 & $4.92 \mathrm{~b}$ & $8.20 \mathrm{a}$ & $4.10 \mathrm{~b}$ & $7.28 \mathrm{a}$ & $0.34 \mathrm{a}$ & $0.37 \mathrm{a}$ & $0.38 \mathrm{a}$ \\
50 & $5.47 \mathrm{~b}$ & $8.68 \mathrm{a}$ & $4.65 \mathrm{~b}$ & $7.65 \mathrm{a}$ & $0.37 \mathrm{a}$ & $0.41 \mathrm{a}$ & $0.44 \mathrm{a}$ \\
65 & $5.72 \mathrm{~b}$ & $8.24 \mathrm{a}$ & $5.11 \mathrm{~b}$ & $6.96 \mathrm{a}$ & $0.29 \mathrm{~b}$ & $0.36 \mathrm{~b}$ & $0.46 \mathrm{a}$ \\
\hline
\end{tabular}

*Means followed by the same lowercase letter in the line do not differ by Tukey test at the 5\% probability level.

Table 7: Height of plants (HP), dry mass of shoots (DMS), productivities of total (PTR) and commercial roots (PCR), productivity of scrap roots (PSR) and dry mass of roots (DMR) of radish intercropped with cowpea for the spatial arrangement and growing season treatments.

\begin{tabular}{|c|c|c|c|c|c|c|}
\hline Spatial arrangement & $\begin{array}{l}\mathrm{HP} \\
(\mathrm{cm})\end{array}$ & $\begin{array}{c}\text { DMS } \\
\left(\mathrm{t} \mathrm{ha}^{-1}\right)\end{array}$ & $\begin{array}{c}\text { PTR } \\
\left(\mathrm{t} \mathrm{ha}^{-1}\right)\end{array}$ & $\begin{array}{c}\text { PCR } \\
\left(\mathrm{t} \mathrm{ha}^{-1}\right)\end{array}$ & $\begin{array}{c}\text { PSR } \\
\left(\mathrm{t} \mathrm{ha}^{-1}\right)\end{array}$ & $\begin{array}{c}\text { DMR } \\
\left(\mathrm{t} \mathrm{ha}^{-1}\right)\end{array}$ \\
\hline $2: 2$ & $16.78 \mathrm{~A}$ & $0.37 \mathrm{~B}$ & $5.80 \mathrm{~B}$ & $4.99 \mathrm{~B}$ & $0.81 \mathrm{~B}$ & \\
\hline $3: 3$ & $17.07 \mathrm{~A}$ & $0.44 \mathrm{~A}$ & $6.74 \mathrm{~A}$ & $5.89 \mathrm{~A}$ & $0.85 \mathrm{~B}$ & \\
\hline $4: 4$ & $16.88 \mathrm{~A}$ & $0.48 \mathrm{~A}$ & $6.99 \mathrm{~A}$ & $5.86 \mathrm{~A}$ & $1.12 \mathrm{~A}$ & \\
\hline \multicolumn{7}{|l|}{ Cropping season } \\
\hline 1 & $16.01 \mathrm{~B}$ & $0.32 \mathrm{~B}$ & & & $0.76 \mathrm{~B}$ & $0.28 \mathrm{~B}$ \\
\hline 2 & $17.81 \mathrm{~A}$ & $0.53 \mathrm{~A}$ & & & $1.10 \mathrm{~A}$ & $0.45 \mathrm{~A}$ \\
\hline
\end{tabular}

${ }^{*}$ Means followed by the same capital letter in the same column do not differ by Tukey test at the $5 \%$ probability level. 
For cowpea, a significant interaction between growing seasons and amounts of $C$. procera incorporated into the soil was observed in the length of green pods, productivity of green pods and yield of green grains variables (Table 8).

Partitioning the length of green pods, productivity of green pods and yield of green grains of cowpea variables by the amounts of $C$. procera within each growing season, an upward pattern of these variables as a function of amount of $C$. procera incorporated into the soil were observed, obtaining a maximum value of 17.14 $\mathrm{cm}, 7.45 \mathrm{t} \mathrm{ha}^{-1}$ and $3.66 \mathrm{t} \mathrm{ha}^{-1}$, following the treatment amount of $65.00 \mathrm{t} \mathrm{ha}^{-1}$ for the first season and values of $16.47 \mathrm{~cm}, 1.84$ and $1.78 \mathrm{t} \mathrm{ha}^{-1}$, following the treatment amounts of $65.00,60.46$ and $60.33 \mathrm{tha}^{-1}$, respectively, for the second season (Figures 3A, 3C and 3F). This pattern in the second harvest is due in part to the low amount of phosphorus present in the soil and the lower content of nutrients determined in the green manure, which was incorporated into the soil in the second growing season (Tables 2 and 3).

According to Graham and Miller (2005), low solubility and translocation of $\mathrm{P}$ in soil solution, actions of microbial enzymes and mycorrhizal associations may be related to decomposing microorganisms that colonize a plant's rhizosphere. However, according to Rincón and Gutiérrez (2012), these processes are influenced by a combination of factors, such as plant species, soil type and environmental factors. This scenario can be partly justified by the environmental conditions presented in the pre-flowering, flowering and maturation periods, with mean temperature differences between the first and second seasons for these periods at 1.09, 0.71 and $0.64{ }^{\circ} \mathrm{C}$ (Figure 1), respectively, resulting in a lower plant efficiencies compared to available natural resources, thus considerably influencing the productive variables of the second season.

According to Craufurd et al. (1998), decrease in grain yield due to elevated temperatures is common in cowpea. Agricultural production is directly linked to climatic conditions, with substantial effects possible from the time of planting to harvesting (Wutke et al., 2000).

An increasing pattern was also observed in the number of pods per $\mathrm{m}^{2}$, dry mass of green pods, number of green grains per pod, weight of 100 green grains and dry mass of green grains of cowpea following treatments with increasing amounts of $C$. procera incorporated into the soil, obtaining maximum values of 149.80 pods $\mathrm{m}^{-2}$, $1.40 \mathrm{tha}^{-1}, 8.82$ grains, $36.76 \mathrm{~g}$ and $1.03 \mathrm{tha}^{-1}$, respectively, with the $65 \mathrm{t} \mathrm{ha}^{-1}$ C. procera treatment (Figures 3B, 3C, $3 \mathrm{D}, 3 \mathrm{E}$ and $3 \mathrm{~F})$.

Through partitioning growing season treatments within each $C$. procera treatment group for cowpea variables, we observed that cowpea yield in the first season was higher than for the second growing season, except for the length of green pods in the $50 \mathrm{t} \mathrm{ha}^{-1}$ treatment group (Table 9). It was verified that the cowpea plants in the first season were more efficient in the use of natural resources for these variables (LGP, PGP and PGG).

Table 8: $F$ values of length of green pods (LGP), number of green pods per $\mathrm{m}^{2}$ (NGP), productivity of green pods (PGP), dry mass of green pods (DMGP), number of green grains per pod (NGGP), weight of 100 green grains (W100GG), yield of green grains (YGG) and dry mass of green grains (DMGG) of cowpea intercropped with radish across growing season, amount of $C$. procera incorporated and spatial arrangement treatments.

\begin{tabular}{|c|c|c|c|c|c|c|c|c|c|}
\hline Sources of variation & DF & LGP & NGP & PGP & DMGP & NGGP & W100GG & YGG & DMGG \\
\hline Blocks (Seasons) & 6 & $0.57^{\text {ns }}$ & $0.84^{\text {ns }}$ & $1.61^{\text {ns }}$ & $0.96^{\mathrm{ns}}$ & $0.58^{\text {ns }}$ & $0.72^{\text {ns }}$ & $1.08^{\text {ns }}$ & $0.96^{\mathrm{ns}}$ \\
\hline Seasons (S) & 1 & $31.55^{* *}$ & $401.01^{* *}$ & $977.24^{* *}$ & $30.47^{* *}$ & $34.73^{* *}$ & $6.02^{*}$ & $347.12^{* *}$ & $24.04^{\star *}$ \\
\hline Amounts (Q) & 3 & $26.26^{* *}$ & $44.33^{\star *}$ & $43.28^{* *}$ & $50.19^{\star *}$ & $16.12^{\star *}$ & $1.53^{\text {ns }}$ & $55.16^{* *}$ & $56.48^{* *}$ \\
\hline Spatial arrangements (A) & 2 & $1.82^{\text {ns }}$ & $1.35^{\mathrm{ns}}$ & $0.55^{\text {ns }}$ & $0.43^{\text {ns }}$ & $2.37^{\mathrm{ns}}$ & $1.18^{\text {ns }}$ & $1.35^{\mathrm{ns}}$ & $0.35^{\text {ns }}$ \\
\hline $\mathrm{S} \times \mathrm{Q}$ & 3 & $4.12^{* *}$ & $2.38^{\text {ns }}$ & $11.33^{* *}$ & $0.70^{\text {ns }}$ & $0.71^{\text {ns }}$ & $0.36^{\mathrm{ns}}$ & $3.30^{*}$ & $0.90^{\text {ns }}$ \\
\hline$S \times A$ & 2 & $2.12^{\mathrm{ns}}$ & $1.51^{\mathrm{ns}}$ & $0.59^{\text {ns }}$ & $0.53^{\text {ns }}$ & $0.35^{\mathrm{ns}}$ & $0.54^{\mathrm{ns}}$ & $2.43^{\text {ns }}$ & $0.78^{\text {ns }}$ \\
\hline$Q \times A$ & 6 & $1.08^{\text {ns }}$ & $1.39^{\text {ns }}$ & $2.01^{\mathrm{ns}}$ & $1.56^{\mathrm{ns}}$ & $1.10^{\text {ns }}$ & $1.50^{\text {ns }}$ & $1.52^{\text {ns }}$ & $1.26^{\mathrm{ns}}$ \\
\hline$S \times Q \times A$ & 6 & $0.72^{\text {ns }}$ & $0.41^{\text {ns }}$ & $0.82^{\mathrm{ns}}$ & $0.51^{\text {ns }}$ & $0.86^{\mathrm{ns}}$ & $0.52^{\text {ns }}$ & $0.46^{\text {ns }}$ & $0.59^{\text {ns }}$ \\
\hline CV (\%) & - & 4.32 & 18.39 & 19.70 & 22.27 & 9.20 & 7.46 & 20.77 & 22.62 \\
\hline
\end{tabular}

${ }^{* *}=\mathrm{P}<0.01 ;{ }^{*}=\mathrm{P}<0.05 ; \mathrm{ns}=\mathrm{P} \geq 0.05$. 

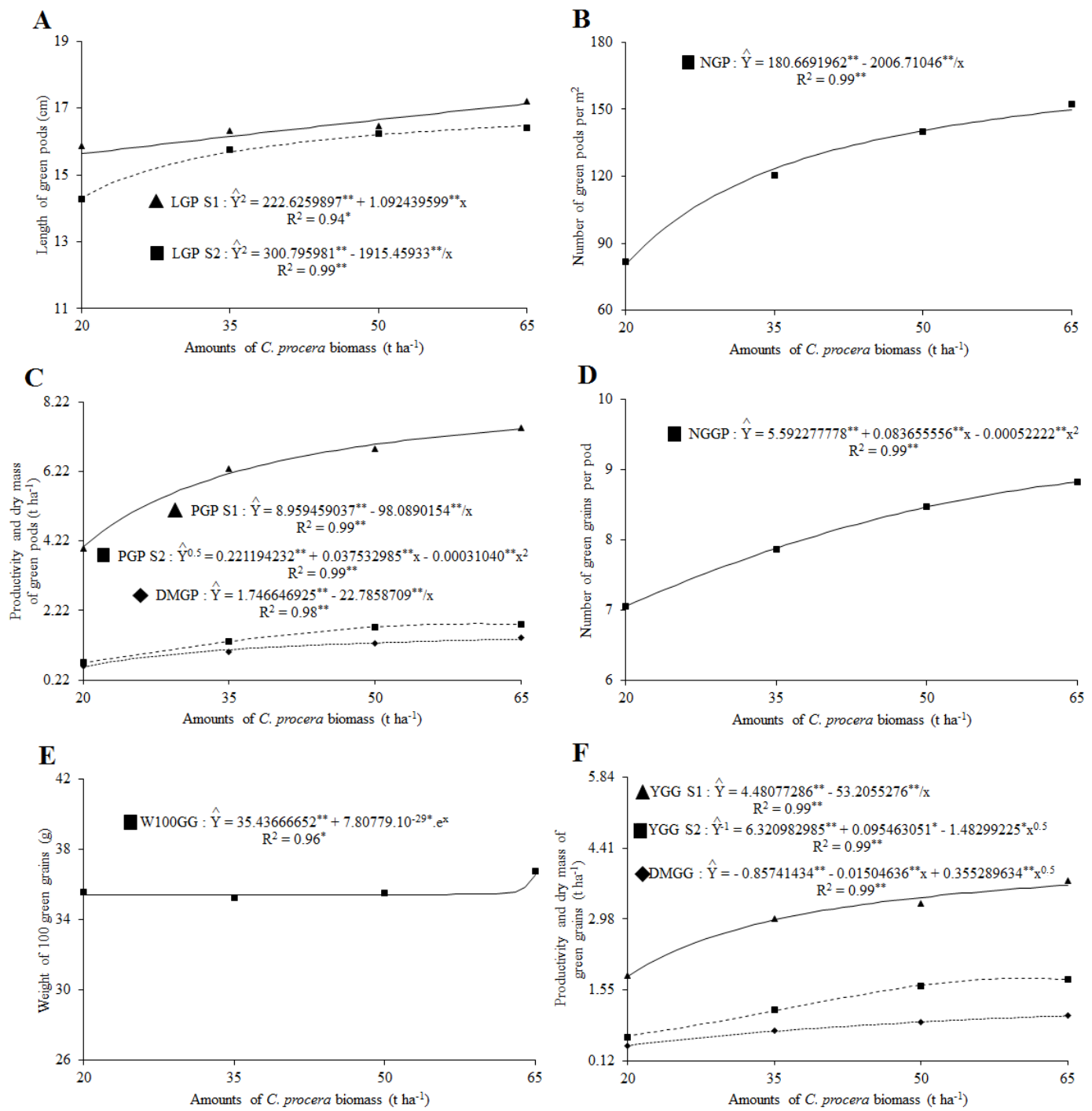

Figure 3: Length of green pods (A), number of green pods per $\mathrm{m}^{2}(\mathrm{~B})$, productivity and dry mass of green pods (C), number of green grains per pod (D), weight of 100 green grains $(E)$ and productivity and dry mass of green grains (F) of cowpea intercropped with radish differing by cropping season and in the amount of $C$. procera incorporated into the soil.

Table 9: Length of green pods (LGP), productivity of green pods (PGP) and yield of green grains (YGG) of cowpea intercropped with radish across cropping seasons and within C. procera treatments.

\begin{tabular}{ccccccc}
\hline \multirow{2}{*}{$\begin{array}{c}\text { Incorporated } \\
\text { amount }\end{array}$} & \multicolumn{2}{c}{$\begin{array}{c}\text { LGP } \\
(\mathrm{cm})\end{array}$} & \multicolumn{2}{c}{$\begin{array}{c}\text { PGP } \\
\left(\mathrm{t} \mathrm{ha}^{-1}\right)\end{array}$} & \multicolumn{2}{c}{$\begin{array}{c}\text { YGG } \\
\left(\mathrm{t} \mathrm{ha}{ }^{-1}\right)\end{array}$} \\
\cline { 2 - 7 } & $1^{\text {st }}$ season & $2^{\text {nd }}$ season & $1^{\text {st }}$ season & $2^{\text {nd }}$ season & $1^{\text {st }}$ season & $2^{\text {nd }}$ season \\
\hline 20 & $15.88 \mathrm{a}$ & $14.29 \mathrm{~b}$ & $4.02 \mathrm{a}$ & $0.72 \mathrm{~b}$ & $1.83 \mathrm{a}$ & $0.60 \mathrm{~b}$ \\
35 & $16.33 \mathrm{a}$ & $15.76 \mathrm{~b}$ & $6.29 \mathrm{a}$ & $1.33 \mathrm{~b}$ & $2.98 \mathrm{a}$ & $1.15 \mathrm{~b}$ \\
50 & $16.47 \mathrm{a}$ & $16.23 \mathrm{a}$ & $6.88 \mathrm{a}$ & $1.75 \mathrm{~b}$ & $3.29 \mathrm{a}$ & $1.63 \mathrm{~b}$ \\
65 & $17.20 \mathrm{a}$ & $16.40 \mathrm{~b}$ & $7.47 \mathrm{a}$ & $1.82 \mathrm{~b}$ & $3.76 \mathrm{a}$ & $1.76 \mathrm{~b}$ \\
\hline
\end{tabular}

*Means followed by the same lowercase letter in the row do not differ by Tukey test at the $5 \%$ probability level. 
Table 10 shows significant difference between growing seasons. Means of weight of 100 green grains, number of green pods per $\mathrm{m}^{2}$, dry mass of green pods, number of green grains per pod and dry mass of green grains in the first season values were all higher than those of the second growing season. These results may be related to the environmental conditions to which the plants were exposed in the first cropping, where the plants reached a balance in the translocation of photoassimilates and their conversion, not only in productive variables but also in growth characteristics.

Intercropping system efficiency, as measured by monetary advantage and modified monetary advantage, no significant interaction between the factors of cropping season, amounts of $C$. procera incorporated into the soil and spatial arrangement between the component cultures (Table 11).

An upward pattern as a function of increasing amount of $C$. procera incorporated into the soil was recorded in both the monetary advantage and modified monetary advantage, where we observed maximum values of $16,632.45$ and $6,777.26 \mathrm{R} \$ \mathrm{ha}^{-1}$ for the 63.22 and 56.44 $\mathrm{t} \mathrm{ha}^{-1}$ treatments, decreasing up to the last added amount. These results show the advantage in monetary terms of fertilizing intercroppings with green manure, indicating economically viable advantages (Figure 4).

No significant difference was observed between the monetary and modified monetary advantages across planting spatial arrangements or across cropping seasons between component cultures (Table 12). These results are evidence that, regardless of spatial arrangement and cropping season, agronomic performances in the crops were complementary and economically positive.

These results are evidence that, regardless of spatial arrangement and cropping season, agronomic performances in the crops were complementary and economically positive. Among the production factors tested, the one that was responsible at a greater scale for the agro-economic efficiency was without doubt the green fertilization, due to $C$. procera dose optimization that results in agronomic efficiency (measured by MA) of this input compared to economic efficiency (measured by MMA). It is known that green manure, when applied in adequate quantity, improves fertility, increases organic matter content, decreases erosion rates and increases soil water retention and soil microbiota activity by increasing nutrient availability and reducing amount of invasive plants (Graham; Haynes, 2006).

Table 10: Length of green pods (LGP), number of green pods per $\mathrm{m}^{2}$ (NGP), dry mass of green pod (DMGP), number of green grains per pod (NGGP), weight of 100 green grains (W100GG) and dry mass of green grains (DMGG) of cowpea intercropped with radish in each cropping season.

\begin{tabular}{cccccc}
\hline Cropping season & $\begin{array}{c}\text { NGP } \\
\left(\mathrm{m}^{2}\right)\end{array}$ & $\begin{array}{c}\text { DMGP } \\
\left(\mathrm{t} \mathrm{ha}{ }^{-1}\right)\end{array}$ & NGGP & $\begin{array}{c}\text { W100GG } \\
(\mathrm{g})\end{array}$ & $\begin{array}{c}\text { DMGG } \\
\left(\mathrm{t} \mathrm{ha}^{-1}\right)\end{array}$ \\
\hline 1 & $170.02 \mathrm{~A}$ & $1.24 \mathrm{~A}$ & $8.50 \mathrm{~A}$ & $35.10 \mathrm{~B}$ & $0.86 \mathrm{~A}$ \\
2 & $77.14 \mathrm{~B}$ & $0.96 \mathrm{~B}$ & $7.61 \mathrm{~B}$ & $36.43 \mathrm{~A}$ & $0.68 \mathrm{~B}$ \\
\hline
\end{tabular}

*Means followed by the same capital letter in the same column do not differ by Tukey test at the $5 \%$ probability level.

Table 11: Fvalues of the monetary advantage (MA) and modified monetary advantage (MMA) of radish intercropped with cowpea at different cropping seasons, amounts of $C$. procera incorporated into the soil and spatial arrangements.

\begin{tabular}{cccc}
\hline SV & DF & MA & MMA \\
\hline Blocks (Seasons) & 6 & $2.22^{\text {ns }}$ & $2.18^{*}$ \\
Seasons (S) & 1 & $1.26^{\text {ns }}$ & $0.32^{\text {ns }}$ \\
Amounts (Q) & 3 & $47.84^{* *}$ & $21.18^{* *}$ \\
Spatial arrangements (A) & 2 & $0.70^{\text {ns }}$ & $0.96^{\text {ns }}$ \\
S X Q & 3 & $1.82^{\text {ns }}$ & $2.27^{\text {ns }}$ \\
S X A & 2 & $2.89^{\text {ns }}$ & $1.87^{\text {ns }}$ \\
Q x A & 6 & $0.83^{\text {ns }}$ & $0.93^{\text {ns }}$ \\
S Q Q X A & 6 & $1.29^{\text {ns }}$ & $1.14^{\text {ns }}$ \\
CV (\%) & - & 40.77 & 56.44 \\
\hline
\end{tabular}

${ }^{*}=\mathrm{P}<0.05 ;{ }^{* *}=\mathrm{P}<0.01 ; \mathrm{ns}=\mathrm{P} \geq 0.05$. 


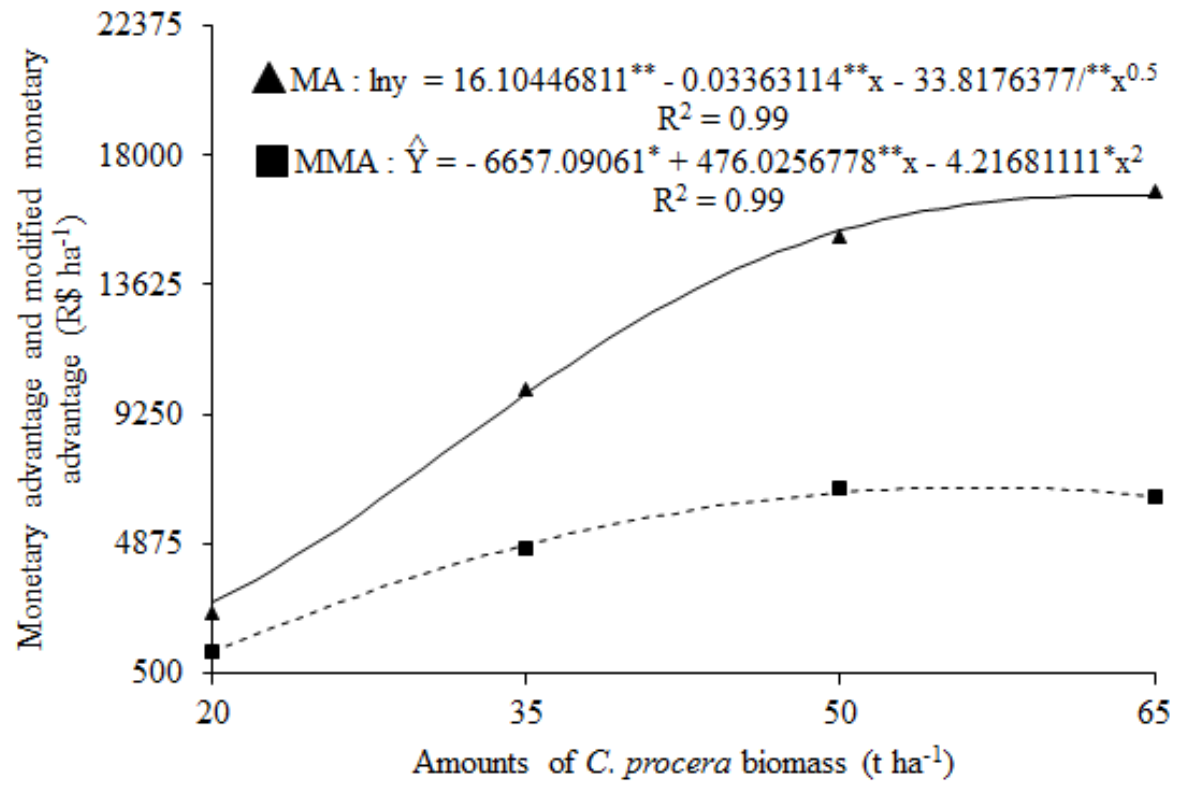

Figure 4: Monetary advantage and modified monetary advantage for each amount of $C$. procera incorporated into the soil.

Table 12: Monetary advantage (MA) and modified monetary advantage (MMA) of the intercropping of radish and cowpea across spatial arrangement and cropping season treatments.

\begin{tabular}{ccc}
\hline Spatial arrangement & MA & MMA \\
\hline $2: 2$ & $10,391.04 \mathrm{~A}$ & $4,244.13 \mathrm{~A}$ \\
$3: 3$ & $11,510.16 \mathrm{~A}$ & $4,936.34 \mathrm{~A}$ \\
$4: 4$ & $11,594.08 \mathrm{~A}$ & $5,133.76 \mathrm{~A}$ \\
Cropping season & & \\
1 & $11,686.40 \mathrm{~A}$ & $4,927.94 \mathrm{~A}$ \\
2 & $10,643.79 \mathrm{~A}$ & $4,614.88 \mathrm{~A}$ \\
\hline
\end{tabular}

*Means followed by the same capital letter in the column do not differ by Tukey test at the 5\% probability level.

Moreover, it is also known that nitrogen and potassium are responsible for the formation of radish roots (Inam et al., 2011) and are considered essential elements for good development of plants, participating in the making of structural compounds or in metabolic functions (Lima et al., 2001). The levels of these two elements in C. procera are at ideal levels, as observed in Table 3.

Silva et al. (2018), studying the efficiency of carrot-lettuce intercropping in semi-arid environments and using different amounts of $C$. procera biomass incorporated into the soil in different spatial arrangements, registered a similar influence of spatial arrangement on intercropping efficiency and greater agronomic efficiency of intercropping at the optimized C. procera biomass of
$46.36 \mathrm{t} \mathrm{ha}^{-1}$. This result was exactly similar to that observed in our research, where among the production factors tested, the green manuring was responsible for the greater efficiency of the intercropping.

On the other hand, Silva et al. (2018) evaluated the effects of different doses of hairy woodrose as green manure on the agro-economic sustainability indicators of beet-lettuce intercropping, in different spatial arrangements and in two successive cropping seasons, but registered no influence of spatial arrangement and greater optimized agro-economic performance of beet-lettuce intercropping with the incorporation of approximately $35.30 \mathrm{t} \mathrm{ha}^{-1}$ of hairy woodrose biomass, with a similar effect of the green manure to that observed in this research. 


\section{CONCLUSIONS}

It is recommended that the radish-cowpea intercropping system incorporates $56.44 \mathrm{t} \mathrm{ha}^{-1}$ of $C$. procera into the soil. The spatial arrangements $3: 3$ and $4: 4$ were the ones that had better productive performances in the intercropping system. Radish intercropping with cowpea is viable when manured with the $C$. procera species of the Caatinga biome.

\section{ACKNOWLEDGEMENTS}

Special thanks are due to the Coordenação de Aperfeiçoamento de Pessoal de Nível Superior for financial support of this research and to the research group of the Department of Agronomic and Forestry Sciences of the Universidade Federal Rural do Semi-Árido (UFERSA) for the development of technologies for growing vegetable crops on family farms.

\section{REFERENCES}

ALLEN, R. G. et al. Crop evapotranspiration: Guidelines for computing crop water requirements. Rome: FAO. Irrigation and Drainage Paper, 56, 1998. 300p.

ALMEIDA, A. E. S. et al. Eficiência agronômica do consórcio alface-rúcula fertilizado com flor-de-seda. Revista Caatinga, 28(3):79-85, 2015.

ARGENTA, G. S. et al. Resposta de híbridos simples de milho à redução do espaçamento entre linhas. Pesquisa Agropecuária Brasileira, 36(1):1-8, 2001.

BATISTA, M. A. V. et al. Atributos microbiológicos do solo e produtividade de rabanete influenciados pelo uso de espécies espontâneas. Horticultura Brasileira, 31(4):587594, 2013.

BEZERRA, F. T. C. et al. Comportamento vegetativo e produtividade de girassol em função do arranjo espacial das plantas. Revista Ciência Agronômica, 45(2):335-343, 2014.

BEZERRA NETO, F. et al. Otimização agroeconômica da cenoura fertilizada com diferentes doses de jitirana. Revista Ciência Agronômica, 45(2):305-311, 2014.

CALEGARI, A. et al. Aspectos gerais da adubação verde. In: COSTA, M. B. B. (Coord.). Adubação verde no sul do Brasil. 2. ed. Rio de Janeiro: Assessoria e Serviços a Projetos em Agricultura Alternativa, 1993. 1-56p.

COSTA, R. G. et al. Perspectivas de utilização da flor-de-seda (Calotropis procera) na produção animal. Revista Caatinga, 22(1):1-9, 2009.
CRAUFURD, P. Q. et al. Heat tolerance in cowpea: Effect of timing and duration of heat stress. Annals of Applied Biology, 133(2):257-267, 1998.

DHIMA, K. V. et al. Competition indices of common vetch and cereal intercrops in two seeding ratio. Field Crops Research, 100(2-3):249-256, 2007.

EMBRAPA - Empresa Brasileira de Pesquisa Agropecuária. Manual de análises químicas de solos, plantas e fertilizantes. 2.ed. Brasília: Embrapa Informação Tecnológica, 2009. 627p.

FAVACHO, F. S. et al. Productive and economic efficiency of carrot intercropped with cowpea-vegetable resulting from green manure and different spatial arrangements. Revista Ciência Agronomica, 48(2):337-346, 2017.

FERREIRA, D. F. Sisvar - Sistema de análise de variância para dados balanceados. Ciência e Agrotecnologia, 35(6):10391042, 2011.

FREIRE FILHO, F. R. Feijão-caupi no Brasil: Produção, melhoramento genético, avanços e desafios. Teresina: Embrapa Meio-Norte, 2011. 84p.

GRAHAM, M. H.; HAYNES, R. J. Organic matter status and the size, activity and metabolic diversity of the soil microbial community in the row and inter-row of sugar cane under burning a trash retention. Soil Biology \& Biochemistry, 38(1):21-31, 2006.

GRAHAM, J.; MILLER, R. Mycorrhizas: Gene to function. Plant and Soil, 274(4):79-100, 2005.

INAM, A. et al. Studies on Potassium content in two root crops under nitrogen fertilization. International Journal of Environmental Sciences, 2(2):1030-1038, 2011.

JANDEL SCIENTIFIC. Table Curve: Curve fitting software. Corte Madera, CA: Jandel Scientific, 1991. 280p.

LIMA, E. V. et al. Adubação NK no desenvolvimento e na concentração de macronutrientes no florescimento do feijoeiro. Scientia Agricola, 58(1):125-129, 2001.

LIMA, J. S. S. et al. Productive performance of carrot and rocket cultivars in strip-intercropping system and sole crops. Agrociencia, 44(4):561-574, 2010.

LINHARES, P. C. F. et al. Quantidades e tempos de decomposição da flor-de-seda no desempenho agronômico do rabanete. Revista Verde de Agroecologia e Desenvolvimento Sustentável, 6(1):168-173, 2011.

OLIVEIRA, K. J. B. et al. Produção agroeconômica da rúcula fertilizada com diferentes quantidades de Calotropis procera. Revista Terceiro Incluído, 5(2):373-384, 2015. 
OLIVEIRA, L. A. A. et al. Viabilidade agronômica de policultivos de rúcula/cenoura/alface sob quantidades de flor-deseda e densidades populacionais. Revista Caatinga, 28(4):116-126, 2015.

OLIVEIRA, L. C. et al. Influência de adubações e manejo de adubo verde nos atributos biológicos de solo cultivado com alface (Lactuca sativa L.) em sistema de cultivo orgânico. Arquivos do Instituto Biológico, 79(4):557-565, 2012.

PEREIRA, M. F. S. et al. Productive performance of cowpearadish intercropping under different amounts of rooster tree biomass incorporated into the soil. Revista Brasileira Engenharia Agrícola Ambiental, 20(11):965-971, 2016.

RÊGO, L. G. S. et al. Pedogenesis and soil classification of an experimental farm in Mossoró, state of Rio Grande do Norte, Brazil. Revista Caatinga, 29(4):1036-1042, 2016.

RIBEIRO, G. M. et al. Productive performance of carrot and cowpea intercropping system under different spatial arrangements and population densities. Revista Caatinga, 31(1): 19-27, 2018.

RINCÓN, L. E. C.; GUTIÉRREZ, F. A. A. Dinámica del ciclo del nitrógeno y fósforo en suelos. Revista Colombiana de Biotecnología, 14(1):285-295, 2012.
SILVA, A. F. A. et al. Rentabilidade do rabanete adubado com flor-de-seda em duas épocas de cultivo no semiárido de Pernambuco. Revista Brasileira de Ciências Agrárias, 58(2): 198-207, 2015.

SILVA, D. J.; QUEIROZ, A. C. Análise de alimentos: métodos químicos e biológicos. 3.ed. Viçosa: UFV, 2002. 235p.

SILVA, I. N. et al. Green manure and spatial arrangement in the sustainability improvement of lettuce-beet intercrops. Revista Brasileira Engenharia Agrícola Ambiental, 22(7):451-457, 2018.

SILVA, R. C. P. et al. Effect of rooster tree green manure on carrot and lettuce intercropping system. Revista Caatinga, 31(3):551-559, 2018.

VIEIRA, C. 0 feijão em cultivos consorciados. In: VIEIRA, C.; PAULA JUNIOR, T. J. de; BORÉM, A. Viçosa: UFV, 2. ed. 2006. p.493-528.

VIEIRA, F. A. et al. Technical-economic efficiency of the yield of green grains of cowpea fertilized with roostertree. Revista Caatinga, 31(2):504-510, 2018.

WUTKE, E. B. et al. Propriedades do solo e sistema radicular do feijoeiro irrigado em rotação de culturas. Revista Brasileira de Ciência do Solo, 24(3):621-633, 2000. 